1986

\title{
Consumer Protection in the United States: Control of Unfair or Unconscionable Practices
}

Phillip Blumberg

University of Connecticut School of Law

Follow this and additional works at: https://opencommons.uconn.edu/law_papers

Part of the Consumer Protection Law Commons, and the Law and Economics Commons

\section{Recommended Citation}

Blumberg, Phillip, "Consumer Protection in the United States: Control of Unfair or Unconscionable Practices" (1986). Faculty Articles and Papers. 184.

https://opencommons.uconn.edu/law_papers/184 


\section{HEINONLINE}

Citation: 34 Am. J. Comp. L. Supp. 991986

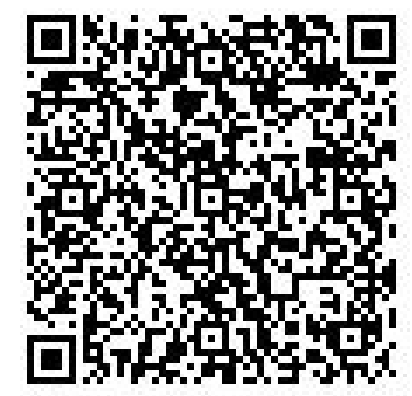

Content downloaded/printed from

HeinOnline (http://heinonline.org)

Tue Aug 16 12:49:10 2016

-- Your use of this HeinOnline PDF indicates your acceptance of HeinOnline's Terms and Conditions of the license agreement available at http://heinonline.org/HOL/License

-- The search text of this PDF is generated from uncorrected OCR text.

-- To obtain permission to use this article beyond the scope of your HeinOnline license, please use:

https://www.copyright.com/ccc/basicSearch.do?

\&operation $=$ go\&search $T y p e=0$

\&lastSearch $=$ simple\&all=on\&titleOrStdNo=0002-919X 


\title{
Consumer Protection In The United States: Control Of Unfair Or Unconscionable Practices
}

\author{
Phillip I. Blumberg*
}

The United States has responded emphatically to the widespread pressures for increased protection of consumers through the enactment on both the federal and the state level of numerous statutes dealing with various areas of concern as well as by more vigorous judicial intervention. This paper presents a summary review of the legal developments that have provided consumers in the United States with protection against practices that are characterized as "unfair" or "unconscionable" even though they are neither deceptive nor misleading. ${ }^{1}$

\section{Federal Statutes and Administrative Regulations}

\section{A. Federal Trade Commission Act}

Section 5 of the Federal Trade Commission Act ("FTCA") is the oldest and most prominent statute for the protection of consumers. ${ }^{2}$ Enacted in 1914, Section 5 authorized the Federal Trade Commission to correct "unfair methods of competition". 3 The statute was in-

* Professor of Law and Business and Former Dean, University of Connecticut School of Law.

1. In order to keep this paper within manageable bounds, it does not discuss any statutory or administrative provisions that do not rely on general references to "unfair" or "unconscionable" acts or practices and instead specify the particular types of acts or practices that are proscribed or made subject to regulation, even though the legislation may represent a judgment as to the unfairness or unconscionability of the acts in question. Nor does the paper discuss the numerous statutes and regulations that provide consumer protection through extensive requirements for disclosure. The alternative would involve reference to the entire panoply of statutory and regulatory materials in the United States pertaining to consumer protection.

2. See generally P. Barron, Federal Regulation of Real Estate par. 5.02[2][b] (rev. ed. 1983) [hereinafter cited as "Barron"]; $1 \mathrm{~S}$. Kanwit, Federal Trade Commission $\S \S 4.01,4.05-4.08$ (1979) [hereinafter cited as "Kanwit"]; Averitt, The Meaning of "Unfair Acts or Practices" in Section 5 of the Federal Trade Commission Act, 70 Geo. L.J. 225 (1981) [hereinafter cited as "Averitt"]; Denger, The Unfairness Standard and FTC Rulemaking: The Controversy over the Scope of the Commission's Authority, 49 Antitrust L.J. 53 (1980) [hereinafter cited as Denger]; Erxleben, The FTC's Kaleidoscopic Unfairness Statute: Section 5, 10 Gonz. L. Rev. 333 (1975); Schwartz, Regulating Unfair Practices under the FTCA: The Need for a Legal Standard of Unfairness, 11 Akron L. Rev. 1 (1977).

3. 15 U.S.C. $\S 45(a)(1)(1976)$. 
tended primarily to deal with anti-competitive practices, but the legislative history shows that the Congress included consumer unfairness as an example of unfair competition. ${ }^{4}$

In its implementation of the statute, the Commission moved to protect consumers, first attacking mislabeling or misbranding as "unfair methods of competition" resulting in injury to consumers. ${ }^{5}$ Similarly after initially emphasizing "deception", the Commission reached out to attack conduct because it was "unfair" even though no "deception" was involved. This significant advance was upheld by the Supreme Court in the Keppel case. ${ }^{6}$

In time, the Commission moved to protect consumers as an objective in and of itself, rather than as an incident that would further competition. Nevertheless, in view of the express statutory reference to "unfair methods of competition," proof of some anti-competitive injury was a necessary element for enforcement of the Commission orders. ${ }^{7}$

To avoid this limitation, Congress in 1938 enacted the WheelerLea Amendment, extending section 5 of the FTCA to cover "unfair or deceptive acts or practices" 8 as well as "unfair methods of competition". 9 With this amendment, the FTCA provided three separate bases for the Commission's jurisdiction: unfairness, or deception, or unfair competitive methods. Many commercial acts or practices have involved two or even three of these elements; in such event, the Commission has often based its action on the various supporting factors involved. ${ }^{10}$

After the enactment of the Wheeler-Lea Amendment, the Commission moved slowly with its new authority in the consumer protection area. The Commission did not at the outset rely solely on "unfairness". The Commission initially continued to confine itself to matters that could be covered by concepts of "unfair competition" or to rely on "deception" as the standard without regard to "unfairness". After a period, the Commission relied both on "deception" and "unfairness" as alternative standards. ${ }^{11}$ Eventually in the final

4. See Averitt, supra note 1, at 229-31.

5. E.g., FTC v. R.F. Keppel \& Bro., 291 U.S. 304 (1934); FTC v. Algoma Lumber Co., 291 U.S. 67 (1934); FTC v. Royal Milling Co., 288 U.S. 212 (1933); FTC v. Winstead Hosiery Co., 258 U.S. 483 (1922).

6. FTC v. R.F. Keppel \& Bro., 291 U.S. 304 (1934).

7. FTC v. Raladam, 283 U.S. 643 (1931).

8. 52 Stat. 49 (1938); 15 U.S.C. $\S 45(a)(1)(1976)$. See H.R. Rep. No. 1613, 75th Cong., 1st Sess. 3 (1937) (The statute "makes the consumer, who may be injured by the unfair trade practice, of equal concern, before the law with the merchant or manufacturer injured by the unfair methods of a dishonest competitor.")

9. See Averitt, supra note 1, at 234-39.

10. See Kanwit, supra note 1, at 4-2.

11. Pfizer, Inc., 81 F.T.C. 23 (1972); All-State Indus., 75 F.T.C. 465 (1969), aff'd, 423 F.2d 423 (4th Cir., cert. denied, 400 U.S. 828 (1970); Rule on Unfair or Deceptive Advertising and Labeling of Cigarettes in Relation to the Health Hazards of Smoking, 29 Fed. Reg. 8324, 8355 (1964). See Averitt, supra note 1, at 240-43. 
stage of this evolutionary process, ${ }^{12}$ the Commission at last relied solely on "unfairness" as an independent basis for its actions, without reliance on "competition" or "deception".13 "Unfairness" as an independent basis for jurisdiction received judicial vindication in the Supreme Court decision in the Sperry \& Hutchinson case. ${ }^{14}$

The statute did not define "unfairness" and a fundamental issue has been the confines of the term. As one commentator has put it: "The potential of the "unfairness" doctrine is almost limitless."15 The Commission made efforts to provide some content to "unfairness" as it moved away from "deception" as an essential factor; it emphasized the "consumer's ability to make an economically rational product choice."16 In the Cigarette Rule, the Commission singled out three basic factors of unfairness:

(1) whether the practice, without necessarily having been previously considered unlawful, offends public policy as it has been established by statutes, the common law, or otherwise-whether, in other words, it is within at least the penumbra of some common-law, statutory or other established concept of unfairness;

(2) whether it is immoral, unethical, oppressive, or unscrupulous;

(3) whether it causes substantial injury to consumers (or competitors or other businessmen). ${ }^{17}$

These factors were favorably noted by the Supreme Court in Sperry $v$. Hutchinson, ${ }^{18}$ and have since been referred to as the $S \&$ $H$ criteria. In 1975, the Magnuson-Moss Warranty-Federal Trade Commission Improvement Act further strengthened the Commission's rule-making and other authority over "unfair and deceptive acts and practices". ${ }^{19}$ The Commission has since relied solely on

12. The history of this evolution is traced in Kanwit, supra note 1 , at $\S 4.05$ and Averitt, supra note 1 , at 239 .

13. See Averitt, supra note 1, at 239.

14. FTC v. Sperry \& Hutchinson Co., 405 U.S. 233 (1972). See Kanwit, supra note 1 , at $\S 4.05$; Averitt, supra note 1 , at $243-45$.

15. See Kanwit, supra note $1, \S 4.05$ at $4-21$.

16. See Pfizer, Inc., 81 F.T.C. 23, 62 (1972); Averitt, supra note 1, at 243.

17. Statement of Basis and Purpose, Unfair or Deceptive Advertising and Labeling of Cigarettes in Relation to the Health Hazards of Smoking, 29 Fed. Reg. 8324, 8355 (1964).

18. FTC v. Sperry \& Hutchinson Co., 405 U.S. 233, 244 n. 5 (1972).

19. P.L. 93-637, 88 Stat. 2183 (1975); 15 U.S.C. $\& 57 \mathrm{a}(\mathrm{a})-(1)(\mathrm{b})$ (1982). Section 202(a) of the Act provided that the Commission may prescribe: "(A) interpretive rules and general statements of policy with respect to unfair or deceptive acts or practices .... and (B) rules which define with specificity acts or practices which are unfair or deceptive ..." Section 206(a) provided for the institution of actions by the Commission for the benefit of consumers, with such remedy to be in addition to other rights and remedies under state or federal law. See Denger, supra note 1, at 63.

The Act also dealt extensively to protect consumers with respect to warranties. One of these provisions is of particular interest. Section 108(b) provides: "implied warranties may be limited in duration to the duration of a written warranty of rea- 
"unfairness" in numerous rules ${ }^{20}$ and cases. ${ }^{21}$ Thus, the Trade Regulation Rule on Credit Practices, effective March 1, 1985, one of the most recent of the Commission's consumer protection rules, ${ }^{22}$ deals with five specified "unfair" credit practices and one "unfair or deceptive" practice. It thus rests primarily on the Commission's "unfairness" jurisdiction.

The Commission's aggressive use of its rule-making power under the Magnuson-Moss Act increased in importance and ultimately became highly controversial. ${ }^{23}$ The indefiniteness of the "unfairness" standard emerged as one of the major elements contributing to high tension in the relationship between the Commission and the Congress. ${ }^{24}$ Thus, Commissioner Robert Pitofsky, a well-respected scholar and liberal FTC commissioner, acknowledged:

many people are legitimately concerned that the term ["unfairness"] is so vague as to be useless in predicting what is legal and so general as to confer on the Commission excessive 'legislative' authority. ... Sperry \& Hutchinson ... . makes even commissioners wonder about the limits of their authority. ${ }^{25}$

Finally in 1980, at the request of the Senate Consumer Subcommittee, the Commission submitted an elaborate statement of its views on the standard of "unfairness" ["1980 Unfairness Statement"] together with an allied statement distinguishing the "unfairness" standard from the "deception" standard.26 The Statement applied both to advertising and non-advertising matters. ${ }^{27}$ It singled out "unjustified consumer injury" as the most important of the three $S$ $\& H$ criteria, sufficient by itself to warrant a finding of unfairness. To constitute unfairness, the consumer injury

sonable duration, if such limitation is conscionable and is set forth in clear and unmistakeable language and prominently displayed on the face of the warranty." 15 U.S.C. $\S 2308(b)(1982)$.

20. E.g., Preservation of Consumers' Claims and Defenses Rule, Statement of Basis and Purpose, 40 Fed. Reg. 53506, 53523 (1975); Advertising of Ophthalmic Goods and Services Rule, Statement of Basis and Purpose, 43 Fed. Reg. 23992, 24001 (1978); Labelling and Advertising of Home Insulation Rule, 44 Fed. Reg. 50218 (1979). See also Proposed Rule affecting commercial advertising which was prohibited by the 1980 Improvement Act. See Barron, supra note 1, par. 5.02-[2][c], at 5-10. $5-9$.

21. See Horizon Corp., 97 FTC 464 (1981); Barron, supra note 1 par. 5.02[2][b], at

22. 49 Fed. Reg. 7740 (1984), codified at 16 C.F.R. pt. 444 (1985). See Butler \& Kaswell, Federal Trade Commission Rulemaking in 1984, 40 Bus. Law. 1119 (1985); Braasch, Recent Developments: Federal Trade Commission Credit Practices Rules, 36 Bus. Law. 1252 (1981).

23. See Denger, supra note 1 , at 63.

24. See Denger, supra note 1.

25. See Pitofsky, in Kirkpatrick, Elman, Pitofsky, and Baxter, Debate: The Federal Trade Commission under Attack: Should the Commission's Role Be Changed?, 49 Antitrust L.J. 1481, 1492 (1980).

26. The FTC statement on "unfairness" [hereinafter cited as "FTC Statement"] is reproduced in Averitt, supra note 1, at 288-95.

27. FTC Statement, supra note 26 , at 5 . 
must be substantial; it must not be outweighed by any countervailing benefits to consumers or competition that the practice produces; and it must be an injury that consumers themselves could not reasonably have avoided. ${ }^{28}$

As examples of substantial injury, the Statement referred to monetary harm, as when sellers coerce consumers into purchasing unwanted goods and services or when consumers buy defective goods or services on credit but are unable to assert against the creditor claims or defenses arising from the transaction [or] [u]nwarranted health and safety risks. (footnotes omitted)

On the other hand, "Emotional impact and other more subjective types of harm" were ordinarily excluded.29

The Commission pointed out that most of its unfairness proceedings dealt with "sales techniques that prevent consumers from effectively making their own decisions." It recognized that although the market was normally self-correcting, it would be necessary to

halt some form of seller behavior that unreasonably creates or takes advantage of an obstacle to the free exercise of consumer decisionmaking. ${ }^{30}$

With regard to the second $S \& H$ criterion pertaining to a violation of public policy, the Commission observed that although it was listed as an independent criterion, it was

used most frequently . . . as a means of providing additional evidence on the degree of consumer injury.

The Commission recognized that sometimes public policy would independently support Commission action where such policy was appropriate for administrative enforcement.

The policy must be clear and well-established . . . declared or embodied in formal sources such as statutes, judicial decisions, or the Constitution as interpreted by the courts, rather than being ascertained from a general sense of national values. The policy should likewise be one that is widely shared, and not the isolated decision of a single state or a single court. ${ }^{31}$

The third criterion of "immoral, unethical, oppressive, or unscrupulous" conduct was recognized as "largely duplicative". The Commission stated that it had never relied on the third criterion as "an independent basis for a finding of unfairness, and it will act in the future only on the basis of the other two."32

The 1980 Statement is the most recent Commission statement on "unfairness". In 1983, the Commission, again in response to a

28. Id. at 5 .

29. Id. at 5-6.

30. Id. at 7.

31. Id., at $9-12$.

32. Id. at 12 . 
Congressional request, issued a comparable statement dealing with the Commission's policy on deceptive acts or practices. ${ }^{33}$ Along with the 1980 Unfairness Statement, the Deceptive Statement represents the definitive statement of the Commission's views on its power under section 5 of the FTCA with respect to consumer protection matters.

During the Carter Administration, the Commission moved aggressively with measures intended for the protection of consumers and stirred up substantial adverse reaction from the business community as noted above. As a result, it lost much political support in the Congress. In a variety of ways, the Congress cut back on the Commission's authority, including enactment of the Federal Trade Commission Improvements Act. ${ }^{34}$ Reflecting this hostility, the Congress on two occasions allowed the Commission's temporary appropriations to run out requiring it to close its doors. ${ }^{35}$

Dwelling on this unhappy history as well as the substantial criticism of the looseness of the "unfairness" standard, 36 the Reagan Administration transition team report on the FTC headed by James C. Miller, III, who was subsequently appointed FTC Chairman, recommended that the Commission issue "a policy protocol or guideline" defining the term "unfair" under Section 5. As noted above, the 1980 Unfairness Statement did precisely that. The transition team also recommended that Congress define the term "unfair" as well. 37

In 1982, the Commission, of which Mr. Miller was then Chairman, recommended that the Congress enact the Commission's unfairness criteria into law; it subsequently also requested codification of the Commission deception criteria. ${ }^{38}$ Bills accomplishing this have been reported out of Committee from time to time, but the

33. See Beales, Criteria for Consumer Protection Cases, in the FTC 1984, at 5983 (C. Smith \& C. White chmn. 1984) (PLI Corp. L. \& P. No. 467). This paper is concerned solely with "unfair" or "unconscionable" practices, and "deceptive" practices are beyond its scope.

34. P.L. 96-252, 94 Stat. 374 (1980).

35. See Denger, supra note 1 , at 54-55.

36. E.g., Report and Recommendations of the Subcommittee on FTC Rulemaking Reform of the Committee on Consumer Financial Services, Section of Corporation, Banking, and Business Law, American Bar Association (final draft Mar. 2, 1981); Denger, supra note 1; Schwartz, Regulating Unfair Practices under the FTC Act: The Need for a Legal Standard of Unfairness, 11 Akron L. Rev. 1 (1977).

37. Conclusions and Recommendations of the Federal Trade Commission Transition Team, 999 Antitrust \& Trade Reg. Rep. (BNA) G-1 to G-3 (Jan. 29, 1981): “The inherent subjectivity of the term "unfairness", together with recent court interpretations, have provided the agency with powers we believe to be far too broad and beyond original Congressional intent. This creates excessive uncertainty on the part of the business community, as well as, paradoxically, a general feeling of "unfairness." ... the Commission should take steps to define the term on its own initiative; complementary action by Congress would be even better."

38. FTC, Federal Trade Commission Law Enforcement in the 1980s (1984), reprinted in The FTC 1984, at 733, 746 (C. Smith \& C. White chmn. 1984) (PLI Corp. L. \& P. No. 467). For a proposed statute, see Maher, The Rule of Law \& FTC: Thesis \& Antithesis? Some Proposals, 86 Dick. L. Rev. 403 (1982). 
Congress has not yet acted. ${ }^{39}$

Under the Reagan Administration, the FTC Bureau of Consumer Protection has given special attention to matters not involving the "unfairness" standard, such as cases of outright fraud and of deceptive and misleading advertising. One area involving "unfairness" that has been emphasized relates to cases where a seller systematically fails to perform its contractual obligations or unilaterally attempts to modify a contract's terms. The Commission has charged that such actions cause substantial injury that consumers cannot reasonably avoid without offering offsetting benefits to consumers. ${ }^{40}$

The two FTC Statements on Unfairness and Deception have reduced, but not eliminated, the tension over the extent of the FTC's jurisdiction in these areas. As acknowledged by the Reagan Administration Director of the FTC Bureau of Consumer Protection speaking as late as 1984:

The FTC Act ... sets out the extraordinarily broad basic mandate of preventing "unfair or deceptive acts or practices." It provides no guidance on what definitions to apply or criteria to consider in regulating a particular practice. Absent a statutory anchor, the Commission has often left the exact bias of proposed rules uncertain. For example, many rule proposals have listed a series of practices that the Commission disliked, characterizing them as "immoral" or "unethical", but offering no clear explanation of the appropriate legal theory. ...

In my judgment, an important step in imposing discipline in rulemaking processes is to convince Congress to define two terms, "unfair" and "deceptive" that comprise the agency's consumer protection juris diction. . . . Both [the FTC Unfairness and the FTC Deception] statements outline and synthesize recent Commission law, and are useful guideposts for the Commission, the public and Congress. But until the standards they articulate are codified, an element of unpredictability and uncertainty will remain. ${ }^{41}$

39. S. 2499, 97th Cong. 2d Sess. § 2 (1982) proposed; "For purposes of this section, unfair acts or practices are acts or practices that have caused or are likely to cause substantial injury to consumers which is not reasonably avoidable by consumers themselves and not outweighed by countervailing benefits to consumers or competition." H.R. 2970, 98th Cong., 1st Sess. 2 (1983) proposed a different standard: "Any determination under the preceding sentence regarding whether an act or practice is an unfair act or practice shall take into account, in addition to other relevant factors, whether such act or practice violates any public policy as established by Federal or State statutes, common law, practices in business or industry, or otherwise. See Barron, supra note 1, par.5.02-[2][c] at 5-10; Barron, supra note 1, at 5-5 (Supp. 1984).

40. FTC, Federal Trade Commission Law Enforcement in the 1980s (1984), in The FTC 1984, at 733, 762-65 (C. Smith \& C. White Chmn. 1984) (PLI Corp. L. \& P. No. 467).

41. Crawford, Bureau of Consumer Protection Overview, in The FTC 1984, at 19, 25-27 (C. Smith \& C. White, Chmn. 1984) (PLI Corp. L. \& P. No. 467). 


\section{B. Other Federal Consumer Protection Statutes}

In addition to its powers under the FTCA, the Federal Trade Commission is charged with obtaining compliance with no less than seven major consumer credit protection statutes enacted in recent years. ${ }^{42}$ These statutes provide their own standards, and the Commission's jurisdiction does not rest on a general standard such as the "unfair or deceptive practices" provision of section 5 of the FTCA. Although several of these statutes do use such terms as "unfair" or "unconscionable", they provide detailed specification of the conduct proscribed. Thus, section 808 of the Fair Debt Collection Practices Act provides:

A debt collector may not use unfair or unconscionable means to collect or attempt to collect any debt.

However, the statute goes on to provide content for its general standard by specifying eight particular collection practices as violations of the Act. ${ }^{43}$

The many federal consumer protection statutes outside of the consumer credit area similarly specify in detail the acts or practices regulated or proscribed or the matters which must be the subject or disclosure. These do not rely on an undefined general conceptual standard such as "unfair" or "unconscionable". 44 Accordingly, they fall outside the scope of this paper. Problems of construction of "unfair acts and practices" thus centers around section 5 of the FTCA.

42. Truth in Lending Act, 15 U.S.C. $\$ \S 1601-46$ (1982); Fair Credit Billing Act, 15 U.S.C. $\S \S 1666-1666 j$ (1982); Consumer Leasing Act, 15 U.S.C. $\S \S 1667-1667 \mathrm{e}$ (1982); Fair Credit Reporting Act, 15 U.S.C. $\$ \S 1681-1681$ t; Equal Credit Opportunity Act, 15 U.S.C. $\S \S 1691-1691 f$ (1982); Fair Debt Collection Practices Act, 15 U.S.C. $\S \S 1692-$ 1692o (1982); Electronic Fund Transfer Act, 15 U.S.C. $\$ \S 1693-1693 r$ (1982). See Fortney, Consumer Credit Compliance and the Federal Trade Commission: Sketching the New Directions, 39 Bus. Law. 1305 (1984).

43. 15 U.S.C. $\S 1692 F$ (1982).

Similarly, outside of the consumer credit area, Section 609 of the Condominium $\&$ Cooperative Conversion Protection and Abuse Act provides for the termination of "unconscionable" leases by cooperative and condominium unit owners. The statute, however, goes on to require that leases must have each of 6 specified characteristics to be deemed "unconscionable" under the Act. 15 U.S.C. § 3608 (1982).

44. E.g., Consumer Product Safety Act, 15 U.S.C. $\S 2051$ (1982); Federal Boat Safety Act, 46 U.S.C. § 1451 (1982); Federal Cigarette Labelling \& Advertising Act, 15 U.S.C. 1331 (1982); Fair Packaging \& Labeling Act, 15 U.S.C. $\$ 1451$ (1982); Federal Hazardous Substances Act, 15 U.S.C. $\S 1261$ (1982); Flammable Fabrics Act, 15 U.S.C. § 1191 (1982); Lead-based Paint Poisoning Prevention Act, 42 U.S.C. § 4801 (1982); Motor Vehicle Information \& Cost Savings Act, 15 U.S.C. § 1911 (1982); National Manufactured Housing Construction \& Safety Standards Act, 42 U.S.C. \$ 5401 (1982); National Mobile Home Construction \& Safety Act, 42 U.S.C. $\$ 5425$ (1982); National Traffic \& Motor Vehicle Safety Act, 15 U.S.C. § 1391 (1982); Poison Prevention Packaging Act, 15 U.S.C. $\$ 1461$ (1982); Consumer-Patient Radiation Health \& Safety Act, 42 U.S.C. $\S 10001$ (1982). 


\section{State Statutes AND Administrative Regulations}

\section{A. Mini-FTC Acts}

The Federal Trade Commission has urged state governments to adopt their own statutes governing unfair or deceptive acts and practices ("Mini-FTC Acts") to reach conduct that did not affect interstate commerce and was, therefore, not subject to federal regulation. ${ }^{45}$ A dozen states have done so. ${ }^{46}$

The Mini-FTC Acts, among other things, typically declare "unfair or deceptive acts or practices" unlawful and provide that in construing the state statute, courts are to be guided by the interpretations of the Federal Trade Commission and the federal courts of Section 5(a)(1) of the federal statute. The Model Mini-FTC Act combines the basic reference to "unfair or deceptive acts and practices" with provisions making unlawful numerous specified acts or practices from the Uniform Deceptive Trade Practices Act and several from the Uniform Consumer Sales Practices Act. The Model Act also provides for administrative enforcement, together with a wide range of public and private remedies. ${ }^{47}$

Many states have adopted consumer protection statutes dealing with the prohibition of specified acts and practices or requiring elaborate disclosure. Although some employ the "unfair or deceptive" standard without following the Model Mini-FTC Act, ${ }^{48}$ others use still other undefined general terms. Kentucky and Massachusetts provide two examples. The Kentucky statute first refers to "unfair, false, misleading, or deceptive acts or practices" and then provides that "unfair shall be construed to mean unconscionable". 49 Massachusetts, a state with a Mini-FTC statute, has, in addition, enacted a statute regulating mobile home parks. Among other things, the statute prohibits park operators from adopting regulations that are "unreasonable, unfair, or unconscionable". ${ }^{50}$

45. FTC, Model Law for State Government (1971). See J. Sheldon, Unfair and Deceptive Acts and Practices $\S$ 1.2.1. (1982).

46. E.g., Conn. Gen. Stat. Ann. § 42-110b (Supp. 1985); Fla. Stat. ch. 501.204 (1983); Hawaii Rev. Stat. ch. 480-2 (1976); Ill. Ann. Stat. ch. 121 1/2 $§ 262$ (Smith-Hurd Supp. 1985); La. Rev. Stat. $\S 51-1405$ (Supp. 1985); Me. Rev. Stat. Ann. ch. 5, $\S 207$ (West 1979); Mass. Gen. L. ch. 93A § 2(a) (1984); Mont. Code Ann. § 30-14-103 (1983); Neb. Rev. Stat. § 55-6102 (1984); N.C. Gen. Stat. § 75-1.1(a) (1981); Ohio Rev. Code Ann. ch. 1345.02 (Page 1979); Vt. Stat. Ann. tit. 9, § 2453 (1984); Wash. Rev. Code $\S 19-86.020$ (1978); W. Va. Code $\S 46 A-6-104$ (1980). Several other states that have not adopted the Model Act have enacted consumer protection statutes dealing with "unfair" acts and practices among other matters. E.g., Cal. Civil Code $\$ \S 1760,1770$ (West 1985); Wis. Stat. Ann. $\S 100.20$ (West 1973). See also S.C. Code $\S 37-5-108,118$; 37-6-118 (1985) (includes "unconscionable agreements or conduct").

47. See D. Rothschild \& D. Carroll, Consumer Protection: Text 7 Materials 88789 (2d ed. 1977).

48. E.g., Wash. Rev. Code Ann. $\S 19.86 .020$ (1978).

49. Ky. Rev. Stat. Ann. $\S 367.170(1)$, (2) (1984).

50. Mass. Gen. Laws ch. $140 \S 32 \mathrm{~K}$ (1974). 


\section{B. Uniform and Model Acts of the Commissioners on Uniform Laws}

The National Conference of Commissioners on Uniform State Laws has approved and proposed no less than ten Model or Uniform Acts dealing with specialized areas of consumer protection for adoption by the various states that provide remedies against "unfair" or "unconscionable" dealings. These include the following:

Uniform Commercial Code ${ }^{51}$

Uniform Consumer Credit Code (1968 and 1974 Acts) ${ }^{52}$

Uniform Consumer Sales Practices Act ${ }^{53}$

Uniform Residential Landlord and Tenant Act ${ }^{54}$

Uniform Land Transactions Act ${ }^{55}$

Uniform Simplification of Land Transfers Act ${ }^{56}$

Uniform Condominium Act ${ }^{57}$

Model Real Estate Time-Share Act ${ }^{58}$

Uniform Planned Community Act ${ }^{59}$

Model Real Estate Cooperative Act ${ }^{60}$

Uniform Common Interest Ownership Act (1982). ${ }^{61}$

This recapitulation does not include other Uniform or Model Acts that protect consumers through prohibition of specified acts or practices or through detailed requirements for disclosure.

\section{Uniform Commercial Code 62}

The provisions of the Uniform Commercial Code dealing with sales and commercial paper attempt to protect purchasers of goods and commercial paper including consumers as well as other purchasers through a requirement of "good faith" and a prohibition of "unconscionable" practices. The provisions of the Code, particularly sections 1-203, 2-302, and 2-719 containing such provisions, have been widely incorporated in subsequent Uniform or Model consumer protection statutes.

Section 1-203 applicable to the Code generally provides:

Every contract or duty within this Act imposes an obligation of good faith in its performance or enforcement. ${ }^{63}$

51. 1 U.L.A. 2 (1976). The statutes are listed in chronological order according to the date promulgated.

52. 7 U.L.A. 233, 601 (1978).

53. 7A U.L.A. 1 (1978).

54. 7A U.L.A. 499 (1978).

55. 13 U.L.A. $546(1980)$.

56. 14 U.L.A. $212(1980)$.

57. 7 U.L.A. 101 (1978).

58. 7A U.L.A. 307 (Supp. 1985).

59. 7A U.L.A. 96 (Supp. 1985).

60. 7A U.L.A. 216 (Supp. 1985).

61. 7 U.L.A. 97 (Supp. 1985).

62. The Uniform Commercial Code has been adopted by all 50 states and by the District of Columbia, Guam, and the Virgin Islands. 1 U. L.A. 1 (Supp. 1985).

63. See D. Rothschild \& D. Carroll, Consumer Protection: Text \& Materials 478- 
Section 1-201(19) provides:

"Good faith" means honesty in fact in the conduct or transaction concerned.

In the case of merchants, section 2-103(1)(b) provides:

"Good faith" ... means honesty in fact and the observance of reasonable commercial standards of fair dealing in the trade.

Section 1-203 has been reenacted in nine other Uniform consumer protection statutes (all except the Uniform Consumer Sales Practices Act) and provides a general requirement in the transactions subject to the statutes. The Uniform Simplification of Land Transactions Act in the statute and the Uniform Condominium Act and the Uniform Common Interest Ownership Act in the Official Comments $^{64}$ are the only Uniform consumer protection statutes adopting the "fair dealing" definition of "good faith". The other statutes concerned solely with consumer problems, rather than with commercial conduct as well, restrict themselves to the "honesty in fact" standard.

Section 2-302(1) contained in Article 2 dealing with sales of goods provides:

(1) If the court as a matter of law finds the contract or any clause of the contract to have been unconscionable at the time it was made the court may refuse to enforce the contract, or it may enforce the remainder of the contract without the unconscionable clause, or it may so limit the application of any unconscionable clause as to avoid any unconscionable result.

The Official Comment makes it clear that this provision was intended to enable courts to police contracts explicitly in terms of unconscionability rather than indirectly by reference to public policy or contractual construction. ${ }^{65}$

Section 2-302 has been renacted in nine other Uniform consumer protection statutes (all except the Uniform Simplification of Land Transfers Act) and provides another fundamental level of protection for consumers. ${ }^{66}$ Section 2-302 was one of the most noteworthy provisions of the Code and has been the subject of enormous discussion in the literature. ${ }^{67}$

84 (2d ed. 1977); Burton, Good Faith Performance of a Contract Within Article 2 of the Uniform Commercial Code, 67 Iowa L. Rev. 1 (1981); Summers, "Good Faith" in General Contract Law and the Sales Provisions of the Uniform Commercial Code, 54 Va. L. Rev. 195 (1968).

64. For caution in reliance on the Comments, see Skilton, Some Comments on the Comments to the Uniform Commercial Code, 1966 Wis. L. Rev. 597.

65. 1 U.L.A. 252 (1976).

66. Three of the states that have adopted to the Uniform Commercial Code have omitted this provision. See J. White \& R. Summers, Uniform Commercial Code 149 (2d ed. 1980).

67. E.g., D. Rothschild \& D. Carroll, Consumer Protection: Text and Materials 508-25 (2d ed. 1977); J. White \& R. Summers, Uniform Commercial Code 147-73 (2d 
As has been widely noted, the Code makes no effort to define unconscionability, and the Official Comment provides limited guidance for courts in their application of this powerful weapon for judicial intervention. The Official Comment states only:

The basic test is whether in the light of the general commercial background and the commercial needs of the particular trade or case, the clauses involved are so onesided as to be unconscionable under the circumstances existing at the time of the making of the contract. . . . The principle is one of the prevention of oppression and unfair surprise .... and not of disturbance of allocation of risks because of superior bargaining power. ${ }^{68}$

The Comment then refers to ten decisions as illustrative of these principles. One must not lose sight of the facts that the Code is concerned with commercial transactions generally, as well as with consumer matters. Thus, section 2-302(2) requires a court considering unconscionability of a contract to receive evidence as to its "commercial setting". In Uniform statutes dealing primarily with consumer protection, the reference to "commercial" is omitted.

Professors White and Summer explain the lack of definition in the Code. They state:

It is not possible to define unconscionability. it is not a concept, but a determination to be made in light of a variety of factors not unifiable into a formula. ${ }^{69}$

As shown by Professor Leff, ${ }^{70}$ the unconscionability doctrine embraces both procedural unconscionability relating to the circumstances under which the contract was made and substantive unconscionability relating to particular clauses in the contract.

Procedural unconscionability includes such matters as high pressure sales tactics, misrepresentation and deceptive practices, and grossly unequal bargaining positions. It involves surprise and oppressive bargaining. Consumers may be left without a meaningful choice. It is most frequently found in cases of consumers with low

ed. 1980); Braucher, The Unconscionable Contract or Term, 31 U. Pitt. L. Rev. 337 (1970); Davenport, Unconscionability and the Uniform Commercial Code, 22 U. Miami L. Rev. 121 (1968); Duesenberg, Practitioner's View of Contract Unconscionability, 8 U.C.C.L.J. 237 (1976); Ellinghaus, In Defense of Unconscionability, 78 Yale L.J. 757 (1969); Harrington, Unconscionability under the Uniform Commercial Code, 10 S. Tex. L.J. 203 (1968); Hillman, Debunking Some Myths about Unconscionability, 67 Corn. L. Rev. 1 (1981); Leff, Unconscionability and the Crowd-Consumers and the Common Law Tradition, 31 U. Pitt. L. Rev. 349 (1970); Leff, Unconscionability and the Code-The Emperor's New Clause, 115 U. Pa. L. Rev. 485 (1967); Murray, Unconscionability: Unconscionability, 31 U. Pitt. L. Rev. 1 (1969); Spanogle, Analyzing Unconscionability Problems, 117 U. Pa. L. Rev. 931 (1969); Speidel, Unconscionability, Assent and Consumer Protection, 31 U. Pitt. L. Rev. 359 (1970); Younger, a Judge's View of Unconscionability, 5 U.C.C. L.J. 348 (1973).

68. 1 U.L.A. 252 (1976).

69. See J. White \& R. Summers, Uniform Commercial Code 151 (2d ed. 1980).

70. See Leff, Unconscionability and the Code-The Emperor's New Clause, 115 U. Pa. L. Rev. 485 (1967). 
economic levels, low educational achievement, lack of buying power, or inadequate command of English. ${ }^{71}$ However, unconscionability may also be imposed on all economic levels, such as where an industry-wide warranty disclaimer required acceptance by consumers in order to obtain a car from any manufacturer, thereby depriving even wealthy consumers of choice. ${ }^{72}$

Substantive unconscionability usually involves either an excessively high price ${ }^{73}$ or the undue restriction of the debtor's remedies or undue expansion of the creditor's rights, such as unacceptable disclaimers of warranty or liability, and unacceptable termination clauses. ${ }^{74}$

Normally both the negotiating factors and the substance of the resulting transaction will be relevant to the determination of whether the contract is unconscionable. But, there may be cases in which all the contract terms would be fair as between the parties in usual circumstances but are unconscionable because one party has relied on the ignorance or lack of understanding of the other in securing the contract. ${ }^{75}$

One area in which the application of the "unconscionability" standard of section 2-302 is not entirely clear relates to disclaimers of warranties. Section 2-316 expressly permits the exclusion or modification of warranties under certain circumstances; it contains no reference to "unconscionability". Commentators initially disagreed on the construction of the Code as to whether a disclaimer clause complying with section 2-316 would be ineffective if "unconscionable" under section 2-302.76 The matter now appears to be nearing resolution. Most courts faced with the issue have recognized that even a disclaimer meeting the requirements of section 2-316 may be "unconscionable." 77 In this connection, it should be noted that the

71. See In re Friedman, 64 A.D.2d 70, 87, 407 N.Y.S.2d 999 (2d Dep't 1978); D. Rothschild \& D. Carroll, Consumer Protection: Text and Materials 515-16 (rev. ed. 1977); J. White \& R. Summers, Uniform Commercial Code 150-55 (2d ed. 1980).

72. See Henningsen v. Bloomfield Motors, Inc., 32 N.J. 358, 161 A.2d 69 (N.J. 1960) (landmark pre-Code decision).

73. E.g., American Home Improvement, Inc. v. MacIver, 105 N.H. 435, 201 A.2d 886 (1964); Toker v. Pearl, 103 N.J. Super. 500, 247 A.2d 701 (1968) (alternative holding); Jones v. Star Credit Corp., 59 Misc.2d 189, 298 N.Y.S.2d 264 (Sup. Ct. 1969); Frostifresh Corp. v. Reynoso, 52 Misc.2d 26, 274 N.Y.S.2d 757 (Dist. Ct. 1966), rev'd on issue of relief, 54 Misc.2d 119, 281 N.Y.S.2d 964 (Sup. Ct. 1967); State v. ITM, Inc., 52 Misc. 2d 39, 275 N.Y.S.2d 303 (Sup. Ct. 1966). See Central Budget Corp. v. Sanchez, 53 Misc.2d 620, 621, 279 N.Y.S.2d 391, 392 (Civ. Ct. 1967).

74. D. Rothschild \& D. Carroll, Consumer Protection: Text and Materials 516-21 (rev. ed. 1977); J. White \& R. Summers, Uniform Commercial Code 155-63 (2d ed. 1980).

75. See Uniform Land Transactions Act, Official Comment, §1-311 note 4, 13 U.L.A. 575 (1980).

76. Compare Leff, Unconscionability and the Code-The Emperor's New Clause, 115 U. Pa. L. Rev. 485, 523 (1967) with Ellinghaus, supra note 66 at 793; Murray, supra note 66, at 45, and Spanogle, supra note 66, at 957.

77. E.g., FMC Finance Corp. v. Murphree, 632 F.2d 413, 418-20 (5th Cir. 1980); A \& M Produce Co. v. FMC Corp., 186 Cal. Rptr. 114, 135 Cal. App. 3d 473 (1982); Industralease Automated \& Scientific Equip. Corp. v. R.M.E. Enterprises, Inc., 58 
Official Comments to four later Uniform or Model acts state with respect to their statutory provisions pertaining to the exclusion or modification of implied warranties:

a warranty disclosure clause, like any other contract clause is subject to a possible court holding of unconscionability. ${ }^{78}$

Section 2-719(3) extends the principle of "unconscionability" to contractual modifications or limitation of remedy with respect to consequential damages. It provides:

Consequential damages may be limited or excluded unless the limitation or exclusion is unconscionable. Limitation of consequential damages for injury to the person is prima facie unconscionable but limitation of damages where the loss is commercial is not. ${ }^{79}$

Some courts have applied section 2-719(3) to invalidate warranty disclaimers that deny the buyer consequential damages. ${ }^{80}$

Subsequent Uniform acts dealing with consumer protection problems have borrowed largely from the Uniform Commercial Code.

\section{Uniform Consumer Credit Code (1974 Act) ${ }^{81}$}

The Uniform Consumer Credit Code promulgated in 1968 and revised in 1974 has had an impact on the development of the law far beyond the 12 jurisdictions in which the 1968 or 1974 Acts have been substantially enacted. Many provisions of the Federal Truth in Lending Act and Federal Reserve Board Regulation $\mathrm{Z}$ are traceable to it and adaptations of the Code have been enacted widely in the credit laws of many states as well as the District of Columbia. ${ }^{82}$

The Act is a comprehensive model statute covering all creditors such as lenders, lessors, and sellers dealing with consumers. It cov-

A.D.2d 482, 396 N.Y.S.2d 427 (2d Dep't 1977). See D. Rothschild \& D. Carroll, Consumer Protection: Text and Materials 579 (2d ed. 1977); J. White \& R. Summers, Uniform Commercial Code 161-62, 471-81 (2d ed. 1980); Fahlgren, Unconscionability: Warranty Disclaimers and Consequential Damage Limitations, 20 St. L. L.J. 435, $437-$ 45 (1976).

78. Official Comments to Uniform Condominium Act $\S 413,7 A$ U.L.A. 215 (1978); Model Real Estate Cooperative Act $\S 4$-115, 7A U.L.A. 296 (Supp. 1985); Model Real Estate Time Share Act § 4-113, 7A U.L.A. 348 (Supp. 1985); Uniform Planned Community Act $\S 4.115,7$ A U.L.A. 181 (Supp. 1985).

79. See Fahlgren, Unconscionability: Warranty Disclaimers and Consequential Damage Limitations, 20 St. L. L.J. 435 (1976); Samuelson, Unconscionability of Excluding Consequential Damages When No Other Remedy Available, 43 U. Pitt. L. Rev. 197 (1981).

80. See J. White \& R. Summers, Uniform Commercial Code 471-81 (2d ed. 1980) ("The interrelationship among $2-302,2-316$, and 2-719(3) has thus become complex and confusing.")

81. The 1974 Act (or its precessor, the 1968 Act) has been adopted by 11 states and Guam (1974 Act: Idaho, Iowa, Kansas, Maine. 1968 Act: Colorado, Indiana, Oklahoma, South Carolina, Utah, Wisconsin, Wyoming, and Guam) 7 U.L.A. 348, 406 (Supp. 1985).

82. Commissioners' Prefatory Note, 1974 Act. 7 U.L.A. 583, 584 (1978). 
ers the total consumer credit process-from advertising to collection. ${ }^{83}$ Among other matters, it deals with specified credit service charges, additional charges, delinquency charges and deferral charges and specified credit practices, together with civil and criminal penalties.

Following section 1-203 of the Uniform Commercial Code, Section 1.110 imposes a general obligation of "good faith", which is defined in the same manner as provided in section 1-201(19).

Section 5-108(1) substantially follows section 2-302 of the Uniform Commercial Code in providing relief in the case of consumer credit transactions (defined in $\$ 1.301(13)$ to include consumer credit sales, leases or loans), where a court that as a matter of law finds:

(a) the agreement or transaction to have been unconscionable at the time it was made, or to have been induced by unconscionable conduct . . .

In section $5.108(2)$, pertaining to the presentation of evidence in cases involving unconscionability, the reference to the "commercial setting" contained in section 2-302(2) of the Uniform Commercial Code has been significantly changed to "setting". The Official Comment explained:

Unlike the UCC, this section is concerned only with transactions involving consumers and the relevant standard of conduct . . . is not that which might be acceptable as between knowledgable merchants but rather that which measures acceptable conduct on the part of a businessman toward a consumer. ${ }^{84}$

Nevertheless, another portion of the Official Comment in the 1968 Act went on to state that section 5-108 of the Act

is intended to make it possible for the courts to police contracts or clauses which are found to be unconscionable. The basic test is whether, in the light of the background and setting of the market, the commercial needs of the particular trade or case, and the condition of the particular parties to the contract, the contract or clauses involved are so onesided as to be unconscionable under the circumstances existing at the time. . . 85

This inconsistent comment is omitted in the Official Comment to the 1974 Act.

It will be noted that section 5.108 literally goes beyond the provisions of section 2-302 of the Uniform Commercial Code in its express reference to unconscionability arising from the manner of inducement. However, this makes no change in substance. The Official Comment to section 2-302 makes it clear that section 2-302 also includes such conduct.

83. Id. at $583-84$.

84. 7 U.L.A. 511 (1978).

85. 7 U.L.A. 510-11 (1978). 
The Act is noteworthy in the specification it provides to illustrate "unconscionable" conduct. Section 5.108(4) added in the 1974 Act provides that in applying the foregoing provision, consideration shall be given to the following factors, among others:

(a) belief by the seller, lessor, or lender at the time a transaction is entered intu that there is no reasonable probability of payment in full ... by the consumer or debtor;

(b) in the case of a consumer credit sale or consumer lease, knowledge by the seller or the lessor at the time of the sale or lease of the inability of the consumer to receive substantial benefits from the property or services sold or leased;

(c) in the case of a consumer credit sale or consumer lease, gross disparity between the price of the property or services sold or leased and the value of the property or services measured by the price at which similar property or services are readily obtainable in credit transactions by like consumers;

(d) the fact that the creditor contracted for or received separate charges for insurance with respect to a consumer credit sale or loan with the effect of making the sale or loan, considered as a whole, unconscionable; and

(e) the fact that the seller, lessor, or lender has knowingly taken advantage of the inability of the consumer or debtor reasonably to protect his interests by reason of physical or mental infirmities, ignorance, illiteracy, inability to understand the language of the agreement, or similar factors.

With respect to the unconscionable collection of consumer credit debts, section $5.108(2)$ provides that if the court as a matter of law finds that:

a person has engaged in, is engaging in, or is likely to engage in unconscionable conduct in collecting a debt arising from that transaction, the court may grant an injunction and award the consumer any actual damages he has sustained.

In applying the foregoing, section $5.108(5)$ provides that consideration shall be given to the following factors, among others:

(a) using or threatening to use force, violence, or criminal prosecution against the consumer or members of his family;

(b) communicating with the consumer or a member of his family at frequent intervals or at unusual hours or under other circumstances so that it is a reasonable inference that the primary purpose of the communication was to harass the consumer;

(c) using fraudulent, deceptive, or misleading repre- 
sentations such as a communication which simulates legal process which gives the appearance of being authorized, issued, or approved by a government, governmental agency, or attorney at law when it is not, or threatening or attempting to enforce a right with knowledge or reason to know that the right does not exist;

(d) causing or threatening to cause injury to the consumer's reputation or economic status by disclosing information affecting the consumer's reputation for creditworthiness with knowledge or reason to know that the information is false; communicating with the consumer's employer before obtaining a final judgment . . . except as permitted by statute or to verify ... employment; disclosing to a person, with knowledge or reason to know that the person does not have any legitimate business need for the information, or in any way prohibited by statute, information affecting the consumer's credit or reputation; or disclosing information concerning the existence of a debt known to be disputed by the consumer without disclosing that fact; and

(e) engaging in conduct with knowledge that like conduct has been restrained or enjoined ... in an civil action by the Administrator against any person pursuant to the provisions on injunctions against fraudulent or unconscionable agreements or conduct. (Section 6.111).

Section 5.108(6) mandates the award of reasonable fees to the attorney for a debtor or consumer in any action in which the court has found unconscionability under subsections (1) and (2). If the court does not find unconscionability and the consumer or debtor claiming it has brought an action known to be groundless, the court shall award reasonable fees to the attorney for the defendant.

Article 6 provides for enforcement by an Administrative officer or agency. The National Conference recommends centralization of all powers of administration in a single official or agency but recognizes that in some states this may not be feasible. ${ }^{86}$ It provides for investigatory powers for the Administrator including the power of subpoena, $(\$ 6.106)$ the issuance of cease and desist orders and court enforcement. ( $\$ \S 6.108,6.110)$, and for rule-making ( $\$ \S 6.403-6.408)$. Section 6.111(1) empowers the administrator to bring an action to restrain a creditor from engaging in a course of:

(a) making or enforcing unconscionable terms or provisions of consumer credit transactions;

(b) fraudulent or unconscionable conduct in inducing consumers to enter into consumer credit transactions;

***

(d) fraudulent or unconscionable conduct in the col-

86. Official Comment, 7 U.L.A. 789 (1978). 
lection of debts arising from consumer credit transactions. ${ }^{87}$

\section{Uniform Consumer Sales Practices Act ${ }^{88}$}

This Act prohibits deceptive and unconscionable consumer sales practices. ( $\$ \S 3$ and 4 ).

Section 4 prohibiting unconscionable practices departs from the limited reference to "unconscionability" unsupported by further statutory specification as in the Uniform Commercial Code and follows section 5.108(4) of the Uniform Consumer Credit Code, supra, in specifying the circumstances to be given consideration in applying the statutory provision. In addition to each of the circumstances specified in section 5.108(4) of the latter Code, Section 4 of the Act includes two others: the "excessively one-sided" nature of the transaction and misleading statements as follows:

(5) that the transaction he induced the consumer to enter into was excessively one-sided in favor of the supplier; or

(6) that he made a misleading statement of opinion on which the consumer was likely to rely to his detriment.

The Uniform Consumer Sales Practices Act differs from the Uniform Commercial Code in other important respects. Under section 4(a) of the Act, unconscionable practises can occur before, during, and after the transaction, whereas in the Uniform Commercial Code, the transaction is to be evaluated in the light of the circumstances at the time. Further, unconscionability may give rise to affirmative relief, rather than serving only as a defense. In summary, "unconscionability" in the Act seems very much like the "unfair or deceptive" standard under the Federal Trade Commission Act. It is of interest, therefore, that the draftsmen, nevertheless, chose to rely on "unconscionability" rather than on "unfair or deceptive."

The Act provides for rule-making ( $\S 6-7 \mathrm{~A}$ ), investigatory powers including the power of subpoena ( $\$ 8)$, and for the institution of declaratory, injunctive, and damage actions, including class actions, by the Enforcing Authority $(\S 9)$ as well as for private actions, including class actions, by consumers ( $\$ \S 11-13$ ).

Apparently because the Act relates to sales practices, rather than to the "performance or enforcement" of a "contract or duty", the provision with respect to good faith contained in section 1-203 of the Uniform Commercial Code, which appears in the other Uniform consumer protection laws, has been omitted.

87. Section 6.111 (3) provides that in applying section 6.111 , consideration shall be given to each of the factors specified in $\$ 5.108(4)$, among others.

88. 7A U.L.A. 1 (1978). This Act has been adopted by three states (Kansas, Ohio, and Utah). Id. 
The Commissioners' Prefatory Note sets forth the justification for special rules for consumer transactions, stating:

It is recognized that, while freedom of contract is generally a desirable goal, there are situations in which good social policy requires that freedom of contract be limited to protect against possible overreaching and defeated expectations as to consumer transactions. ${ }^{90}$

Section 1-301 of the Act includes the basic requirement of "good faith" in performance and enforcement contained in section 1-203 of the Uniform Commercial Code; the term is not defined. Similarly, section 1-311 of the Act contains the provisions with respect to unconscionable contracts and contract clauses set forth in section 2-302 of the Uniform Commercial Code. ${ }^{91}$ It is interesting to note that the "unconscionability" provision is applicable to the entire Uniform Land Transfers Act. In contrast, the Uniform Commercial Code provision appears not as a principle of general application in Article 1 of the Code but in Article 2 dealing with sales of goods. As a matter of form, it is arguable that the provision applies only to sales and does not apply to the balance of the Code, such as the provisions on secured transactions. However, as might be expected, it has not been so limited. ${ }^{92}$ In any event, a comparable argument is foreclosed in the Uniform Land Transfers Act. ${ }^{93}$

Section 2-311, dealing with the exclusion or modification of warranties of quality departs from the Uniform Commercial Code. It provides:

(e) Any disclaimer of warranties is subject to the provisions or [sic] unconscionability (section 1-311) even though the Seller has complied with subsection (b) or (c) [of section 2-311 permitting certain exclusions or modifications. $]^{94}$

As noted above, Section 2-316 of the Code dealing with exclusion or modification of warranties contains no reference to unconscionability, and its definitional and other cross references do not include section 2-302 dealing with unconscionability. Accordingly, as discussed, the interrelation of sections $2-302$ and $2-316$ is still not entirely clear. ${ }^{95}$

89. 13 U.L.A. 545 (1980).

90. 13 U.L.A. 539 (1980).

91. See Brown, Article 1 of The Uniform Land Transfers Act: Is Inconsistency with the UCC an Unnecessary Obstacle?, 1981 S. Ill. L.J. 585, 588-89.

92. See In Re Elkins-Dell Mfg. Co., 253 F. Supp. 864, 873-74 (E.D. Pa. 1966).

93. See Brown, Article 1 of The Uniform Land Transfers Act: Is Inconsistency with the UCC an Unnecessary Obstacle?, 1981 S. Ill. L.J. 585, 588-89.

94. 13 U. L.A. 612-13 (1980).

95. See J. White \& R. Summers, Uniform Commercial Code 471-81 (2d ed. 1980). 


\section{Uniform Residential Landlord and Tenant Act ${ }^{96}$}

Section 1-302 of the Act imposes the standard obligation of good faith in the performance or enforcement of rights and duties under the Act derived from section 1-203 of the Uniform Commercial Code.

Section 1-303 contains the standard provision with respect to unconscionable agreements or provisions, adapted from section 2-203 of the Uniform Commercial Code, which appears in all the Uniform consumer protection acts, except the Uniform Simplification of Land Transfers Act. Section 1.303(b) follows the model of the Uniform Consumer Credit Code and not the Uniform Commercial Code in referring to "the setting" and not to "the commercial setting" in its provisions on the presentation of evidence on unconscionability.

Section 1.403 prohibits specified provisions in rental agreements and section 5.101 prohibits retaliatory conduct for such acts of the tenant as complaints to governmental agencies or to the landlord about the condition of the premises, or for participation in a tenants' union.

\section{Uniform Simplication of Land Transfers Act ${ }^{97}$}

Section 1-301 of the Act imposes the standard obligation of "good faith" derived from section 1-203 of the Uniform Commercial Code. Section 1-201(6) defines "good faith" to mean:

honesty in fact and the observance of reasonable standards

of fair dealing in the conduct or transaction involved.

The inclusion of "reasonable standards of fair dealing" is noteworthy in its reference to the usage of the trade and its departure from the primary emphasis on the protection of consumers which appears in so many of the other Uniform acts. In brief, the Act moves very close to the Uniform Commercial Code definition of "good faith" for merchants as the standard for all persons under its provisions.

It is also noteworthy that the Act does not include an "unconscionability" provision.

\section{Uniform Condominium Act ${ }^{98}$}

The Uniform Condominium Act was promulgated in 1977 and revised in 1980 .

Section 1-112(a) of the 1980 Act contains the "unconscionability" standard of section 2-302 of the Uniform Commercial Code. In the provision on the presentation of evidence, section 1-112(b)(1) follows the Uniform Commercial Code, rather than the Uniform Consumer

96. 7A U.L.A. 499 (1978). The act has been adopted by 13 states (Alaska, Arizona, Florida, Hawaii, Iowa, Kansas, Kentucky, Montana, Nebraska, New Mexico, Oregon, Tennessee, and Virginia.)

97. 14 U.L.A. 212 (1980).

98. The 1977 Act has been adopted by 2 states and the 1980 Act by four states. 7 U.L.A. 225, 235 (Supp. 1985). 
Credit Code or the Uniform Residential Landlord \& Tenant Act and specifies evidence on "the commercial setting". As noted above in the discussion of the Uniform Consumer Credit Code, the term "commercial" was deliberately omitted in such Code to reflect the emphasis on the protection of consumer rights. Thus, the reference to "commercial" in this Act is a departure from the usual consumer protection concerns. It reflects the higher economic, and presumably educational, levels of the persons apt to be affected by the Act.

Similarly, Section 1-113 of the Act imposes the general obligation of "good faith" contained in section 2-103(1)(b) of the Uniform Commercial Code, but the Act contains no definition of the term. The Official Comment advises that:

Good faith ... means observance of two standards, "honesty in fact" and observance of reasonable standards of fair dealing. 99

This construction follows the model of section 1-301 of the Uniform Simplication of Land Transfers Act ${ }^{100}$ in departing from a primary emphasis on consumer protection. However, the definition in the latter Act appears in the Act itself, not in a Comment.

Section 3-105(3) of the Act provides that "any contract or lease that is not bona fide or was unconscionable to the unit owners" entered into prior to the assumption of control by the unit owners may be terminated without penalty.

\section{Model Real Estate Time-Share Act ${ }^{101}$}

Section 1-105 of the Act, like section 1-112 of the Uniform Condominium Act contains the standard "unconscionability" provision contained in section 2-302 of the Uniform Commercial Code. In the provision relating to the presentation of evidence, section 1-105(b)(1) follows the Uniform Condominium Act and refers to "the commercial setting".

Section 1-106 imposes the standard obligation of good faith contained in section 1-203 of the Uniform Commercial Code. Although the Act does not define the term, the Official Comment sets forth the twin standard of "honesty in fact" and "observance of reasonable standards of fair dealing"102 contained in the Comment to the Uniform Condominium Act. ${ }^{103}$

Section 3-105 provides for the termination of management and employment contracts, leases of recreational or parking areas or facilities, other contracts with the developer or affiliates or "any contract or lease that is not bona fide or was unconscionable" by the new board of the association or by the time-sharer owners in very

99. See 7 U.L.A. 132 (1978).

100. This is noted in the Official Comment. Id

101. 7A U.L.A. 308 (Supp. 1985).

102. 7A U.L.A. 316 (Supp. 1985).

103. 7 U.L.A. 132 (1978). 
much the same terms as contained in section 3-105 of the Uniform Condominium Act.

\section{Uniform Planned Community Act ${ }^{104}$}

Section 1-112 of the Act closely follows section 1-112 of the Model Real Estate Cooperative Act in adapting the standard unconscionability provision of section 2-203 of the Uniform Commercial Code. The provisions on presentation of evidence refer to "the commercial setting" and include similar consumer protection clauses pertaining to parties taking "advantage of the inability of the other party reasonably to protect his interests" and to "gross disparity" of price.

Section 113 imposes the standard good faith obligation of section 1-203. It follows the pattern of the Uniform Condominium Act and the Model Real Estate Time Share Act. It does not define the term, but the Official Comment points to the twin standards of "honesty in fact" and "reasonable standards of fair dealing". 105

Section 4-115 deals with exclusion or modification of implied warranties of quality. The Official Comment notes:

a warranty disclaimer clause, like any other contract clause,

is subject to a possible court holding of unconscionability. ${ }^{106}$

\section{Model Real Estate Cooperative Act ${ }^{107}$}

Section 1-112 of the Act contains the standard "unconscionability" provision contained in section 2-302 of the Uniform Commercial Code. Like the Uniform Condominium Act and the Model Real Estate Time Share Act, the provision relating to the presentation of evidence refers to "the commercial setting." In this respect, it differs from the Uniform Consumer Credit Code. However, the Act also includes in the evidence that may be presented on the issue of unconscionability such consumer protection factors as taking "advantage of the inability of the other party reasonably to protect his interests" and "gross disparity" or price, that are contained in the latter Code.

Section 1-113 contains the standard provision imposing an obligation of good faith contained in section 1-203 of the Uniform Commercial Code. As in the Uniform Condominium Act and the Model Real Estate Time Share Act, the term is not defined with the Official Comment referring to the twin standards of "honesty in fact" and "observance of reasonable standards of fair dealing."

Section 3-105(iii) of the Act follows the Model Real Estate Time Share Act and provides for the termination by the executive board

104. 7A U.L.A. 96 (Supp. 1985).

105. 7A U.L.A. 118 (Supp. 1985).

106. 7A U.L.A. 191 (Supp. 1985).

107. 7A U.L.A. 216 (Supp. 1985). 
elected by the proprietary lessees of any "contract or lease" entered into before the board takes office

that is not bona fide or was unconscionable to the proprietary lessees at the time entered into under the circumstances then prevailing.

"Bona fide" is a new element that appears in none of the other Uniform acts other than the Model Real Estate Time-Share Act.

\section{Uniform Common Interest Ownership Act ${ }^{108}$}

Section 112(a) of the Act sets forth the "unconscionability" standard contained in section 2-302 of the Uniform Commercial Code. Section $112(\mathrm{~b})(1)$ relating to the evidence to be considered, along with the Model Real Estate Cooperative Act departs from the other Uniform consumer acts refers to the "commercial" setting of the negotiation.

Section 113 contains the standard provision with respect to "good faith" contained in section 1-203 of the Code. The Act contains no definition, but, as in the case of the Uniform Condominium Act, the Official Comment refers to honesty in fact and reasonable standards of fair dealing. ${ }^{109}$

\section{COMmON LAW DEVELOPMENT}

Unconscionability has been a recognized doctrine in the law for at least two centuries. ${ }^{110}$ Thus, Justice Frankfurter stated:

Does any principle in our law have a more universal application than the doctrine that courts will not enforce transactions in which the relative positions of the parties are such that one has unconscionably taken advantage of the necessities of the other. ${ }^{111}$

In a number of major decisions prior to the adoption of the Uniform Commercial Code, American courts made progress in articulating standards for determining unconscionability in contract. ${ }^{112}$ Thus, a standardized warranty disclaimer and remedy limitation used throughout the automobile industry was held invalid in Henningsen v. Bloomfield Motors; the court noted the "grossly unequal" bargaining position of the consumer, who had no alternative other than to accept the clause if he wanted an automobile. ${ }^{113}$ Extremely one-sided provisions with respect to the repossession of household

108. 7 U.L.A. 97 (Supp. 1985). Connecticut is the only state that has adopted the Act.

109. 7 U.L.A. 118 (Supp. 1985).

110. Cf. Earl of Chesterfield v. Janssen, 2 Ves. Sr. 125, 28 Eng. Rep. 82, 100 (Ch. 1750); Hume v. United States, 132 U.S. 406, 410 (1889).

111. See United States v. Bethlehem Steel Corp., 315 U.S. 289, 326 (1942) (dissenting).

112. E.g., Henningsen v. Bloomfield Motors, Inc., 32 N.J. 358, 161 A.2d 69 (N.J. 1960); Williams v. Walker-Thomas Furniture Co., 350 F.2d 445 (D.C. Cir. 1965).

113. 161 A.2d 69, 84-87, 94-95 (N.J. 1960). 
goods sold to a poor person of limited education were stricken as unconscionable in Williams $v$. Walker-Thomas Furniture Co. ${ }^{114}$

The Official Comment to section 2-302 contains references to seven other cases holding unconscionable clauses dealing with disclaimer of warranties or limitation of remedies ${ }^{\mathbf{1 1 5}}$ and to three others dealing with other substantive matters. ${ }^{116}$ Accordingly, section 2-302 of the Uniform Commercial Code in some measure is to be seen as a codification of the common law.

The adoption of numerous federal and state consumer protection statutes has not halted the continuing development of the common law doctrine of unconscionability in contract law. On the contrary, section 2-203 of the Uniform Commercial Code, in form applicable only to contracts for the sale of goods, has been used by courts as a useful guide to examining unconscionability in contracts generally. ${ }^{117}$

Thus, section 205 the Restatement (Second) of Contracts borrows from the provisions of section 1-203 of the Uniform Commercial Code to impose a requirement of "good faith and fair dealing".118 Section 208 of the Restatement sets forth the "unconscionability" standard of section 2-302 of the Code. ${ }^{119}$ These provisions, of course, apply to contract law generally, not merely to consumer contracts. The influence of the Uniform laws is apparent. Thus, the Reporter's Note to section 208 states that section 2-302 of the Code has been:

very influential in non-sales cases. It has many times been used either by analogy or because it was felt to embody a generally accepted social attitude of fairness going beyond its statutory application to sales of goods. ${ }^{120}$

114. 350 F.2d 445 (D.C. Cir. 1965).

115. Hardy v. General Motors Acceptance Corp., 38 Ga. App. 463, 144 S.E. 327 (1928); New Prague Flouring Mill Co. v. Spears, 194 Iowa 417, 189 N.W. 815 (1922); Bekkevold v. Potts, 173 Minn. 87, 216 N.W. 790 (1927); Meyer v. Packard Cleveland Motor Co., 106 Ohio St. 328, 140 N.E. 118 (1922); Kansas City Wholesale Grocery Co. v. Weber Packing Corp., 93 Utah 414, 73 P.2d 1272 (1937); Andrews Bros. v. Singer \& Co., [1934] 1 K.B. 17 (C.A.); Robert A. Munroe \& Co. v. Meyer, [1930] 2 K.B. 312.

116. Kansas Flour Mills Co. v. Dirks, 100 Kan. 376, 164 P. 273 (1917); Austin Co. v. J.H. Tillman Co., 104 Or. 541, 209 P. 131 (1922); Green v. Arcos, Ltd. [1931] 47 T.L.R. 336 (C.A.)

117. See In re Elkins-Dell Mfg. Co., 253 F. Supp. 864, 873-74 (E.D. Pa. 1966); Hamm v. Taylor, 180 Conn. 491, 429 A.2d 946, 948-49 (1980).

118. As noted above, section 1-203 refers only to "good faith" while the reference to "fair dealing" is borrowed from the definition of "good faith" applicable to merchants contained in section 2-103 of the Code.

119. Restatement (Second) of Contracts $\S \S 205,208$ (1981). The Reporter's Note to $\S 208$ illustrates "unconscionability" by reference to the specifications contained in Uniform Consumer Credit Code \$ 6-111.

120. See Restatement (Second) of Contracts $\S 208$, comment a, at 111-12 (1981). See also, e.g., Seabrook v. Commuter Housing Co., 72 Misc.2d 6, 338 N.Y.S.2d 67 (Civ. Ct. 1972); Kugler v. Romain, 58 N.J. 522, 279 A.2d 640 (1970); C \& J Fertilizer Inc. v. Allied Mut. Ins. Co., 227 N.W.2d 169, 179-81 (Iowa 1975).

Cases applying Restatement $\S 208$ include: Steinhardt v. Rudolph, 422 So. $2 d$ 
It has even been suggested that further common law development may yet occur in tort. It has been suggested that the contract decisions collectively together with the expression of public policy represented by the unconscionability provisions in numerous statutes may lead to the development of a new remedy in tort: the tort of unconscionability. ${ }^{121}$

Unconscionability goes well beyond unfairness, and there has been no comparable development in the decisions with respect to unfairness, except to the extent that the obligation of "good faith" and "fair dealing" contained in Restatement section 205 may provide relief. In the consumer protection area, "unfairness"-not so extreme as to be characterized as "unconscionability"-may give rise to a remedy only if an applicable statute or administrative regulation so provides, as under section 5(a) of the Federal Trade Commission Act or the Mini-FTC and related acts in the states.

\section{CONCLUSION}

The legal development in the United States in the area of consumer protection is an acknowledgment of the inability of the market satisfactorily to deal with important consumer problems and the need for aggressive intervention by the legal system to achieve the desired level of rights for consumers. This development reflects a realization that judicial intervention through the application of common law standards is inadequate and that legislative intervention is essential. It further reflects the realization that statutory standards of a general nature are less effective than the specific delineation of proscribed acts and practices. Finally, it demonstrates that notwithstanding statutory specificity, only enforcement by a regulatory authority with rule-making power can provide the necessary flexibility to deal effectively with the changing needs of a dynamic commercial society.

884, 889 (Fla. Dist. Ct. App. 1982); Strong v. Oakwood Hospital Corp., 118 Mich. App. 359, 325 N.W.2d 435, 437 (1982); Casey v. Lupkes, 286 N.W.2d 204, 207-08 (Iowa 1979).

121. See King, The Tort of Unconscionability: A New Tort for New Times, 23 St. L. L.J. 97 (1979). 
